\title{
CGP 4832, A NEW SEMISYNTHETIC RIFAMYCIN DERIVATIVE HIGHLY ACTIVE AGAINST SOME GRAM-NEGATIVE BACTERIA
}

\author{
W. Wehrli, W. ZimmermanN, W. Kump, W. Tosch, \\ W. VISCHER and O. ZAK \\ Research Department, Pharmaceuticals Division, Ciba-Geigy Limited, \\ CH-4002 Basel, Switzerland
}

(Received for publication April 27, 1987)

\begin{abstract}
CGP 4832 (5) is a new derivative of rifamycin S, showing a very high degree of activity against certain Gram-negative bacteria, with MICs as much as 400 times lower than those of rifampicin. CGP 4832 and rifampicin inhibit DNA-dependent transcription in vitro to a similar extent, which excludes any difference in their effect on the target enzyme. The most plausible explanation for the potent activity of CGP 4832 is that it penetrates into bacterial cells by way of a specific mechanism. This hypothesis is corroborated by the high rate of mutations leading to bacterial strains resistant against CGP 4832 .
\end{abstract}

In our search for rifamycin derivatives with good activity against Gram-negative bacteria, we discovered a new derivative, CGP 4832 (5, Fig. 1), with MICs for certain Gram-negative species such as Escherichia coli and Salmonella up to 400 times lower than those of rifampicin. The present paper describes the antibacterial properties of this derivative as well as some experiments aimed at determining its mechanism of action.

\section{Materials and Methods}

\section{Chemical Methods}

Organic solutions were dried with anhydrous sodium sulfate. Evaporation was carried out

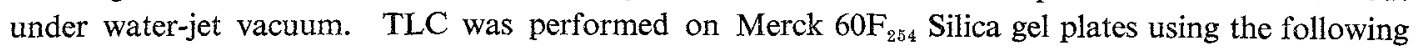
solvent systems: DCl (ethyl acetate), DC2 (methylene chloride-acetone, 9.5:0.5), DC3 (ethyl acetate-methanol, 1:1). Preparative chromatography was carried out on Merck 60 silica gel. ${ }^{1} \mathrm{H}$ NMR spectral ${ }^{\dagger}$ analysis was carried out in $\mathrm{CDCl}_{3}$ at $360 \mathrm{MHz}$; signals are given in $\delta$, ppm (TMS: $\delta 0.0$ or $\mathrm{CHCl}_{3} \delta^{3} 7.28$ ).

3-Morpholinorifamycin S-21,23-acetonide (2) ${ }^{\dagger \dagger}$

After addition of a few drops of concentrated sulfuric acid, a solution of $60 \mathrm{~g}$ 3-morpholinorifamycin S (1) in $600 \mathrm{ml}$ anhydrous acetone and $60 \mathrm{ml}$ 2,2-dimethoxypropane was left to stand for 3 hours at room temp. It was then neutralized with aqueous sodium bicarbonate solution and mixed with a concentrated $\mathrm{NaCl}$ solution, and the reaction product was extracted with methylene chloride. After drying and evaporation of the methylene chloride solution, 3-morpholinorifamycin S-21,23acetonide (2) crystallized from ether as dark-green prisms with a metallic sheen. Recrystallization from methanol - water yielded $60 \mathrm{~g}$ of reddish-violet, silk-lustred crystals without $\mathrm{mp}$.

Rf (DC1) 0.56, (DC2) 0.35; ${ }^{1} \mathrm{H}$ NMR $\delta 0.82(\mathrm{~s}), 1.20$ (s, acetonide- $\left.\mathrm{CH}_{3}\right), 2.00$ (s, 25- $\mathrm{OOCCH}_{3}$ ); field desorption mass spectrum (FD-MS) $m / z 820\left(\mathrm{M}^{+}, \mathrm{C}_{44} \mathrm{H}_{56} \mathrm{~N}_{2} \mathrm{O}_{13}\right)$.

+ Only signals characteristic of the respective compounds are given. All further signals correspond to the typical shifts of rifamycins ${ }^{8)}$.

it Rifamycin skeleton numbered according to OPPOLZER et al. ${ }^{12)}$. 
25-O-Deacetyl-3-morpholinorifamycin S-21,23-acetonide (3)

$50 \mathrm{~g}$ of 3-morpholinorifamycin S-21,23-acetonide (2) was treated for 16 hours with $600 \mathrm{ml}$ of $5 \%$ methanolic sodium hydroxide solution. Ice was then added, the solution acidified with citric acid, and the reaction product extracted with methylene chloride. After drying and evaporation of the methylene chloride solution, $30 \mathrm{~g}$ of 25-O-deacetyl-3-morpholinorifamycin S-21,23-acetonide (3) crystallized from ether as fine, grayish-violet-colored crystals with an $\mathrm{mp}$ of $215^{\circ} \mathrm{C}$.

Rf (DC1) 0.54, (DC2) 0.20; ${ }^{1} \mathrm{H}$ NMR $\delta 0.90(\mathrm{~s}), 1.1$ (s, acetonide- $\mathrm{CH}_{3}$ ), $\mathrm{OCOCH}_{3}$ signal at $\sim 2.0$ missing; FD-MS $m / z 778\left(\mathrm{M}^{+}, \mathrm{C}_{42} \mathrm{H}_{54} \mathrm{~N}_{2} \mathrm{O}_{12}\right)$.

\section{5-O-Deacetyl-25-O-malonic Acid-3-morpholinorifamycin S-21,23-acetonide (4)}

A solution of $30 \mathrm{~g} \mathrm{(3)}$ and $13 \mathrm{~g}$ malonic acid in $180 \mathrm{ml}$ absolute THF was cooled to $0^{\circ} \mathrm{C}$ and stirred. Upon addition of $26 \mathrm{~g}$ dicyclohexylcarbodiimide (DCCI), the reaction began immediately. After 5 minutes, the precipitated dicyclohexylurea was removed by filtration and the filtrate extracted with ethyl acetate, washed with sodium bicarbonate, citric acid and sodium chloride solution, dried and evaporated. Upon chromatography ( $1 \mathrm{~kg}$ silica gel; eluent: ethyl acetate - methanol, $9: 1)$, the residue yielded $25 \mathrm{~g} \mathrm{(4)}$ as the main extract, which crystallized from ether as dark-bluish-green crystals (mp $\left.170^{\circ} \mathrm{C}\right)$.

Rf (DC1) $0.11 ;{ }^{1} \mathrm{H}$ NMR $\delta 3.36$ (s), malonic acid methylene group; FD-MS $m / z 864\left(\mathrm{M}^{+}\right.$, $\mathrm{C}_{45} \mathrm{H}_{58} \mathrm{~N}_{2} \mathrm{O}_{15}$ ).

\section{CGP $4832(5)$}

$8.7 \mathrm{~g}$ morpholinorifamycin-acetonide-malonic acid (4) was reacted with $3.38 \mathrm{~g}$ hydroxybenzotriazole (HBT) in $100 \mathrm{ml}$ absolute THF at $0^{\circ} \mathrm{C}$ for 2 hours while stirring. $3.23 \mathrm{~g}$ 3-hydroxymethyl1 -methylpiperidine and $5.15 \mathrm{~g} \mathrm{DCCI}$ were then added and the reaction mixture stirred for a further 2 hours at $0^{\circ} \mathrm{C}$ and thereafter for 10 hours at room temp. After removal of the precipitated dicyclohexylurea by filtration, the filtrate was concentrated to $50 \mathrm{ml}$ and $20 \mathrm{ml}$ of $20 \%$ sulfuric acid added. After 1 hour the solution was neutralized with sodium bicarbonate, the reaction product extracted with ethyl acetate, and the extract dried and evaporated. Chromatographic purification of the black evaporation residue on $800 \mathrm{~g}$ silica gel first with methylene chloride - methanol $(9: 1)$ yielded a small amount of an urea derivative of 4 , then the quinone of the compound sought (5) was obtained as the main component of an eluate with methylene chloride - methanol $(2: 1)$.

Rf (DC3) 0.83; ${ }^{1} \mathrm{H}$ NMR (100 MHz) (ref TMS $\left.\delta 0.0\right) \delta 2.25\left(\mathrm{~s}, \mathrm{NCH}_{3}+\right.$ aromatic $\left.\mathrm{CH}_{3}\right), 3.38$ (s, malonic ester- $\left.\mathrm{CH}_{2}\right)$; FD-MS $m / z 935\left(\mathrm{M}^{+}, \mathrm{C}_{49} \mathrm{H}_{85} \mathrm{~N}_{3} \mathrm{O}_{15}\right)$; UV $\lambda_{\max }$ (alcohol) nm $(\varepsilon) 217(28,600)$, $271(27,100), 321(14,400), 540(2,300)$.

Materials

$\overline{\left[{ }^{3} \mathrm{H}\right] \mathrm{CTP}}$ was purchased from Radiochemical Centre, Amersham, the nucleotides from SERVA (Heidelberg, Germany).

Bacterial Strains

E. coli $\mathrm{F} 464$ and its mutants F 612, F 539, F 583 and F 515 were a generous gift from K. JANN. E. coli strain W 3110 was obtained from W. ARBER. All the other microorganisms were strains from our own collection.

\section{Measurement of RNA Synthesis}

Highly purified RNA polymerase holoenzyme from $E$. coli ETH 2018 was isolated according to the methods of BurGess ${ }^{12}$ or BERG et al. ${ }^{2)}$ and MANGEL ${ }^{3)}$. The activity of the enzyme was tested as described earlier ${ }^{4)}$. Permeabilization of bacterial cells with ether was carried out as described earlier ${ }^{5,8)}$. DNA-dependent transcription in permeabilized cells was performed as follows: $0.25 \mathrm{ml}$ assay mixture contained Tris- $\mathrm{HCl}$ (pH 8.0) $40 \mathrm{~mm}$, spermidine- $\mathrm{HCl}(\mathrm{pH} 8.0) 8 \mathrm{mM}$, mercaptoethanol $8 \mathrm{~mm}, \mathrm{MgCl}_{2} 8$ $\mathrm{mm}, \mathrm{NH}_{4} \mathrm{Cl}(\mathrm{pH} 8.0) 128 \mathrm{~mm}$, K-phosphate (pH 8.0) $0.5 \mathrm{~mm}$, sucrose $0.5 \mathrm{M}$, ATP, GTP and UTP 1.2 $\mathrm{mM},\left[{ }^{3} \mathrm{H}\right] \mathrm{CTP}(10 \mathrm{mCi} / \mathrm{mmol}) 0.4 \mathrm{~mm}$ and cell protein $c a .40 \mu \mathrm{g}\left(c a .4 \times 10^{7}\right.$ permeabilized bacterial cells $)$. The reaction was started by addition of the four nucleotides. After 10 minutes incubation at $37^{\circ} \mathrm{C}$, the reaction was stopped by addition of $3 \mathrm{ml}$ cold $12 \%$ trichloroacetic acid. Samples were kept in ice for 
60 minutes before filtration through glass fiber filters (Whatman $\mathrm{GF} / \mathrm{C}$ ). The filters were washed 12 times with $5 \mathrm{ml}$ of cold $5 \%$ trichloroacetic acid, then dried for 30 minutes at $100^{\circ} \mathrm{C}$, and radioactivity was determined by scintillation counting. The blanks were obtained by stopping the reaction with trichloroacetic acid immediately after addition of the nucleotides.

\section{Measurement of the Resistance Mutation Rate}

The rate of mutation towards resistance against CGP 4832 was measured using the fluctuation test described by Luria \& Delbrück ${ }^{7)}$.

\section{Results}

\section{Chemical Preparation of CGP 4832}

To produce CGP 4832 (see Fig. 1), rifamycin $\mathrm{S}$ was first converted by reaction with morpholine to give 3-morpholinorifamycin $\mathrm{S}(\mathbf{1})^{8)}$. In this compound the $\mathrm{OH}$ groups at $\mathrm{C}-21$ and $\mathrm{C}-23$ are pro-

Fig. 1. Formula scheme.
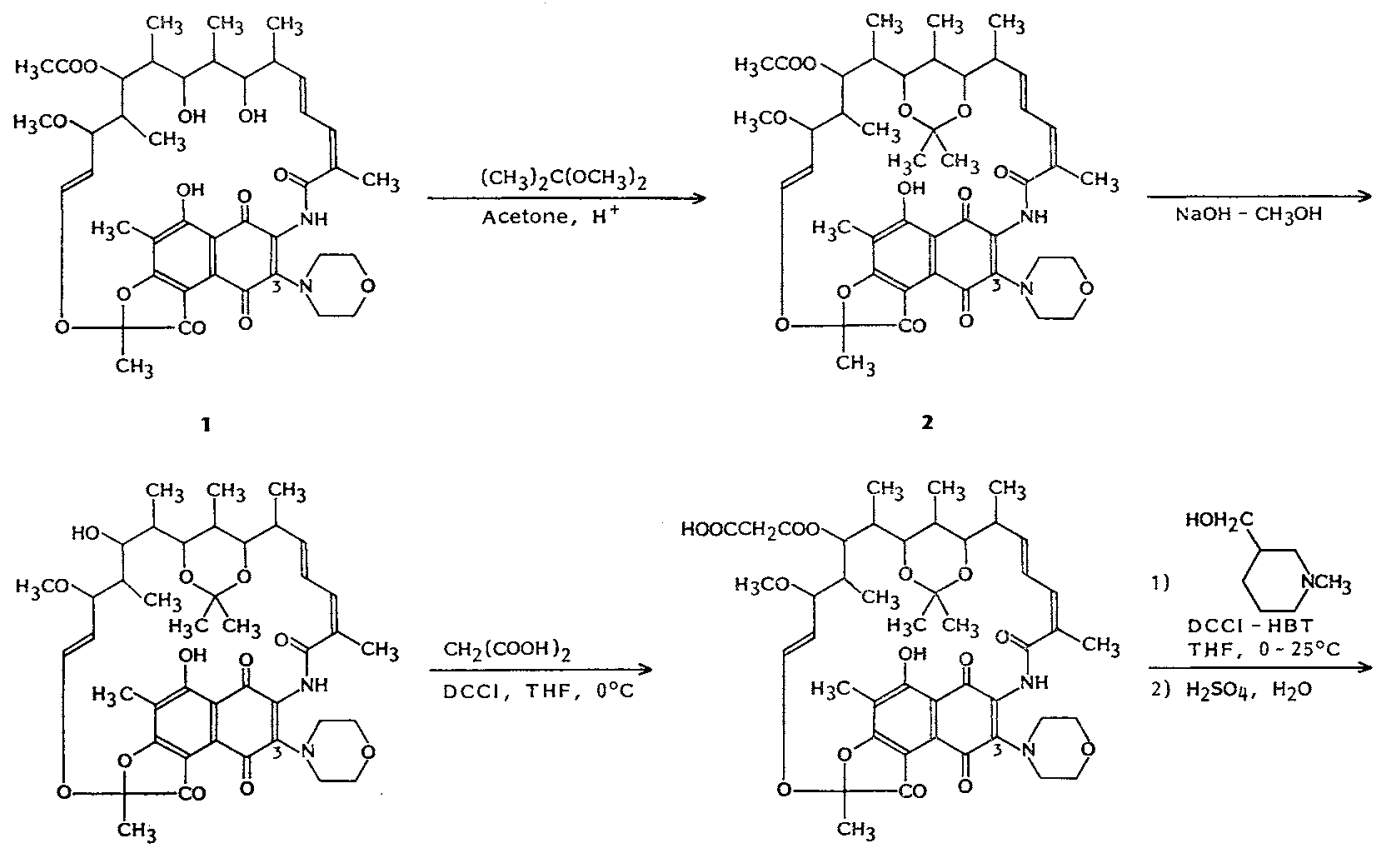

3

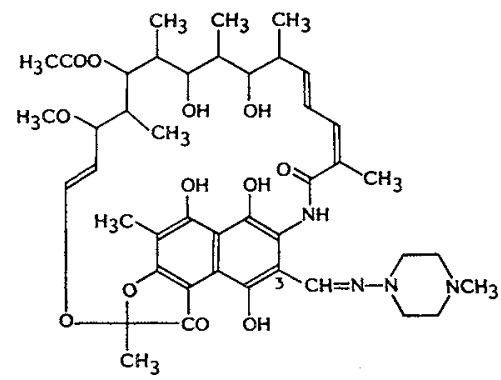

CGP 4832 (5) MW 935 
tected by acetonide formation (2) and $O$-acetyl at $\mathrm{C}-25$ is saponified with $\mathrm{NaOH}$ to $\mathrm{OH}$ (3). Then in an unexpectedly rapid and straightforward reaction of $\mathbf{3}$ with malonic acid and DCCI, the semiester (4) was produced. That was converted by the established procedure with 3-hydroxymethyl-1methylpiperidine, HBT and DCCI, followed by acetonide cleavage to the malonic ester derivative (5). In accordance with its preparation from racemic 3-hydroxymethyl-1-methyl piperidine, CGP 4832 is a diastereomeric mixture.

\section{Antimicrobial Activity}

As shown in Table 1, CGP 4832 is comparable to rifampicin in its activity against Gram-positive bacteria. Against certain Gram-negative species, however, it is $80 \sim 400$ times more potent than rifampicin. In a more detailed study, 105 clinical isolates of $E$. coli and 30 of Salmonella were analyzed. Figs. 2 and 3 show that the MIC of rifampicin for practically all isolates of both bacterial species was around $16 \mu \mathrm{g} / \mathrm{ml}$, whereas two categories of strains can be distinguished in respect of their sensitivity to CGP 4832 : Two thirds of the strains are only $2 \sim 4$ times more sensitive to CGP 4832 than to rifampicin, whereas the remainder are $1 \sim 3$ orders of magnitude more sensitive.

Some strains of Klebsiella and Enterobacter highly sensitive to CGP 4832 have also been isolated (see Table 1). However, marked sensitivity appears to be much less common among these genera than with $E$. coli and Salmonella.

\section{Effect of CGP 4832 on RNA Synthesis}

To ascertain whether the greater sensitivity of the bacterial strains described above could be

Table 1. The antimicrobial spectrum of CGP 4832 and rifampicin.

\begin{tabular}{|c|c|c|}
\hline \multirow{2}{*}{ Microorganism } & \multicolumn{2}{|c|}{$\operatorname{MIC}(\mu \mathrm{g} / \mathrm{ml})$} \\
\hline & CGP 4832 & Rifampicin \\
\hline Staphylococcus aureus $10 \mathrm{~B}$ & 0.01 & 0.01 \\
\hline S. aureus Wood 46 & 0.001 & 0.001 \\
\hline Streptococcus pyogenes, Aronson & 0.01 & 0.01 \\
\hline S. faecalis D 3 & 4 & 1 \\
\hline Escherichia coli 205 & 8 & 8 \\
\hline E. coli 205 rifampicin-resistant & $>128$ & $>128$ \\
\hline E. coli $\mathrm{ETH} 2018$ & 0.01 & 4 \\
\hline E. coli K-12 W 3110 & 0.02 & 8 \\
\hline E. coli $\mathrm{B} 25$ & 0.03 & 8 \\
\hline E. coli B 45 & 0.06 & 8 \\
\hline E. coli $\mathrm{B} 114$ & 0.06 & 16 \\
\hline Salmonella typhimurium 277 & 8 & 16 \\
\hline Salmonella AX 5 & 0.5 & 16 \\
\hline Klebsiella pneumoniae C 14 & 32 & 32 \\
\hline K. pneumoniae 327 & 16 & 8 \\
\hline K. pneumoniae $\mathrm{C} 16$ & 1 & 16 \\
\hline Serratia marcescens & 16 & 16 \\
\hline Enterobacter cloacae P 99 & 16 & 16 \\
\hline E. cloacae ATCC 13047 & 1 & 16 \\
\hline Proteus mirabilis 774 & 16 & 4 \\
\hline P. vulgaris $\mathrm{S} 10$ & 16 & 16 \\
\hline Morganella morganii 2359 & 8 & 4 \\
\hline Pseudomonas aeruginosa ATCC 12055 & 4 & 4 \\
\hline
\end{tabular}

Assayed on brain heart infusion agar. 
Fig. 2. MICs of CGP 4832 and rifampicin for 105 Escherichia coli strains (clinical isolates).

Number of strains per MIC. Rifampicin, CGP 4832.

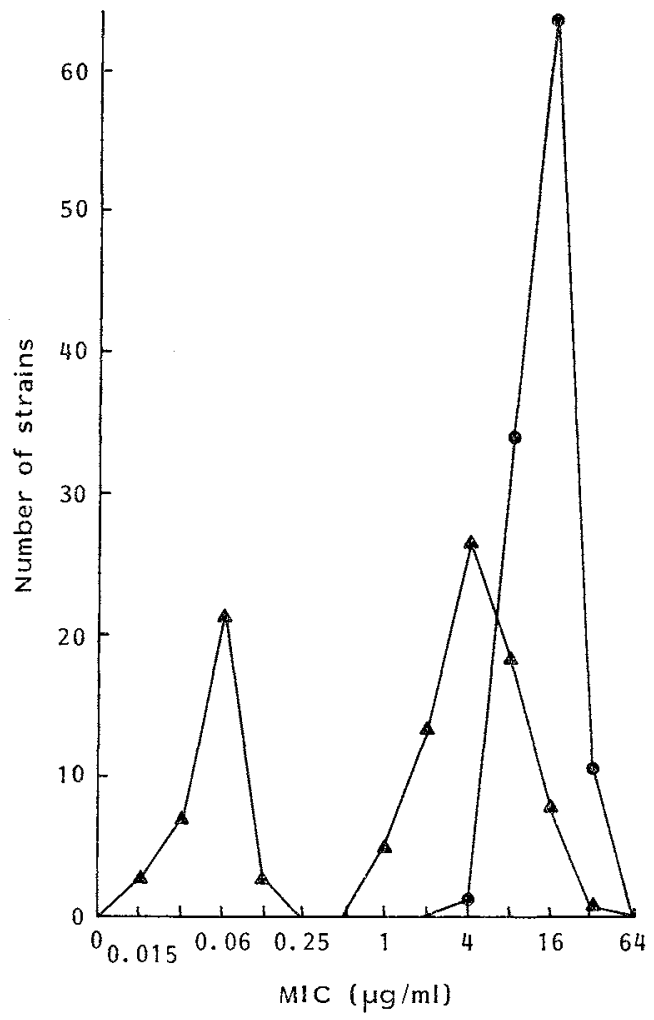

Fig. 3. MICs of CGP 4832 and rifampicin for 30 Salmonella strains (clinical isolates).

Number of strains per MIC. Rifampicin, 4 CGP 4832.

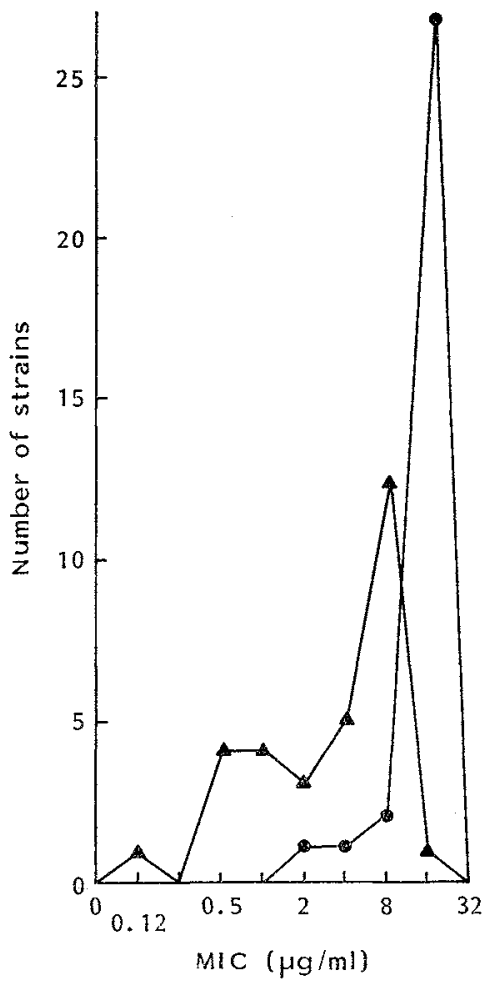

Table 2. Comparison between the antibacterial activity and the inhibition of various bacterial RNA polymerases by CGP 4832 and rifampicin.

\begin{tabular}{|c|c|c|c|c|}
\hline \multirow[b]{2}{*}{$\begin{array}{l}\text { Bacterial strains used for } \\
\text { measuring MICs and } \\
\text { RNA polymerase }\end{array}$} & \multicolumn{2}{|c|}{ CGP 4832} & \multicolumn{2}{|c|}{ Rifampicin } \\
\hline & $\underset{(\mu \mathrm{g} / \mathrm{ml})}{\mathrm{MIC}}$ & $\begin{array}{c}\mathrm{ED}_{50} \\
\text { enzyme } \\
(\mu \mathrm{g} / \mathrm{ml})\end{array}$ & $\underset{(\mu \mathrm{g} / \mathrm{ml})}{\mathrm{MIC}}$ & $\begin{array}{c}\underset{\text { enzyme }_{50}}{\mathrm{ED}_{50}} \\
(\mu \mathrm{g} / \mathrm{ml})\end{array}$ \\
\hline Escherichia coli $\mathrm{ETH} 2018$ & 0.01 & 0.09 & 4 & 0.02 \\
\hline E. coli ETH 2018 , highly purified enzyme & - & 0.06 & - & 0.02 \\
\hline E. coli 205 & 8 & 0.06 & 8 & 0.02 \\
\hline E. coli B 25 & 0.03 & 0.34 & 8 & 0.10 \\
\hline E. coli B 114 & 0.06 & 1.16 & 16 & 0.24 \\
\hline E. coli $\mathrm{K}-12 \mathrm{~W} 3110$ & 0.02 & 0.05 & 8 & 0.02 \\
\hline Salmonella typhimurium 277 & 8 & 0.07 & 16 & 0.03 \\
\hline Salmonella sp. AX 5 & 0.5 & 0.14 & 16 & 0.06 \\
\hline Klebsiella pneumoniae C 14 & 32 & 0.08 & 32 & 0.03 \\
\hline K. pneumoniae $\mathrm{C} 16$ & 1 & 0.6 & 16 & 0.15 \\
\hline Proteus vulgaris $\mathrm{S} 10$ & 16 & 0.14 & 16 & 0.14 \\
\hline
\end{tabular}

a Concentration of CGP 4832 or rifampicin needed to induce $50 \%$ inhibition of RNA polymerase. The substances were in the hydroquinone form. As quinones they are $2 \sim 5$ times less active. The enzyme from E. coli ETH 2018 was highly purified; in all other cases the enzyme activity was measured by using ether permeabilized cells. 
attributable to stronger inhibition of the target enzyme, DNA-dependent RNA polymerase ${ }^{8,10)}$ we analyzed a series of different bacterial strains. As shown in Table 2, there is no correlation between MIC and enzyme inhibition. A comparison with rifampicin demonstrated that, in general, CGP 4832 is $2 \sim 5$ times less potent in its action on the RNA polymerase. The low MICs for certain Gramnegative strains consequently cannot be due to better enzyme inhibition.

Antibacterial Activity of CGP 4832 against $E$. coli Mutants

with Defects in their Cell Envelope

An obvious explanation for the superior activity of CGP 4832 against certain bacteria might be that it penetrates more easily and more rapidly through the cell wall than rifampicin. We therefore determined the antibacterial activity of the two rifamycin derivatives against a range of $E$. coli mutants with known defects in their lipopolysaccharide structure.

The parent strain, E. coli $\mathrm{F} 464$, contains the complete core oligosaccharide, while in the mutants F 612 to F 515 the oligosaccharides are smaller and less complete. E. coli F 515 contains 2-keto-3deoxyoctanate as the only sugar moiety ${ }^{11}$. The data given in Table 3 clearly show that none of the lipopolysaccharide mutants tested is as sensitive to CGP 4832 as some E. coli wild-type strains are. There is a considerable increase in sensitivity to CGP 4832 from the wild-type F 464 to the deep-rough mutant F 515, but this is accompanied with a completely parallel increase in sensitivity to rifampicin. Defects in lipopolysaccharide structure therefore cannot be responsible for the high activity of CGP 4832 against some $E$. coli strains.

\section{Rate of Resistance to CGP 4832}

Mutants resistant to CGP 4832 were selected under two different conditions. Using $100 \mu \mathrm{g} / \mathrm{ml}$ of drug, resistant mutants were obtained at a rate very similar to that found with rifampicin (Table 4). However, after exposure of the bacteria to only $1 \mu \mathrm{g} / \mathrm{ml}$ CGP 4832 the rate of mutation was 50 100 times higher. For most mutants produced in this way, the MICs of rifampicin and CGP 4832 were similar. Thus, high sensitivity of certain $E$. coli strains against CGP 4832 can be converted in a one-step mutation to normal sensitivity, as to rifampicin.

Table 3. Antibacterial activity of CGP 4832 and rifampicin against Escherichia coli mutants with defects in their lipopolysaccharide structure.

For a detailed description of the mutants see ref 11 .

\begin{tabular}{ccc}
\hline \multirow{2}{*}{$\begin{array}{c}\text { E. coli } \\
\text { strain }\end{array}$} & \multicolumn{2}{c}{ MIC $(\mu \mathrm{g} / \mathrm{ml})$} \\
\cline { 2 - 3 } & CGP 4832 & Rifampicin \\
\hline F 464 & 32 & 16 \\
F 612 & 32 & 32 \\
F 539 & 2 & 0.5 \\
F 583 & 1 & 0.5 \\
F 515 & 0.5 & 0.25 \\
\hline
\end{tabular}

Table 4. Rate of resistance of Escherichia coli strain B 45 to CGP 4832 and rifampicin.

\begin{tabular}{lcc}
\hline Type of mutation & $\begin{array}{c}\text { Selecting agent } \\
\text { and condition }\end{array}$ & $\begin{array}{c}\text { Rate of mutation } \\
\left(\times 10^{-8}\right)\end{array}$ \\
\hline CGP $4832^{\mathrm{s}} \rightarrow$ CGP $4832^{\mathrm{R}}$ rif s a $^{\text {CGP } 4832^{\mathrm{s}} \rightarrow \text { rif }^{\mathrm{Bb}}}$ & $1 \mu \mathrm{g} / \mathrm{ml} \mathrm{CGP} \mathrm{4832}$ & 50 \\
rif $^{\mathrm{s}} \rightarrow$ rif $^{\mathrm{Rb}}$ & $100 \mu \mathrm{g} / \mathrm{ml} \mathrm{CGP} \mathrm{4832}$ & 0.44 \\
\hline
\end{tabular}

a Mutants no longer highly sensitive to CGP 4832 , but still inhibited by rifampicin and CGP 4832 at the usual concentrations of $8 \sim 16 \mu \mathrm{g} / \mathrm{ml}$.

b Mutants resistant to at least $100 \mu \mathrm{g} / \mathrm{ml}$ rifampicin or CGP 4832 .

rif: Rifampicin, ${ }^{\mathrm{S}}$ : sensitive, ${ }^{\mathrm{R}}$ : resistance. 


\section{Discussion}

The new rifamycin derivative CGP 4832 is up to 400 times more active than rifampicin against certain Gram-negative bacteria. This greater potency is not due to stronger inhibition of the target enzyme, RNA polymerase. There are no indications of inactivation of rifampicin, or activation of CGP 4832, by the sensitive microorganisms. It is therefore reasonable to assume that the penetration of CGP 4832 into the bacterial cell is somehow facilitated. Lipopolysaccharides do not seem to play a decisive role, since mutants having defects in the lipopolysaccharide structure are affected in a similar way by CGP 4832 and rifampicin. The high mutation rate to CGP 4832-resistance could point to a single protein responsible for the transport of CGP 4832.

\section{References}

1) Burgess, R.: A new method for the large-scale purification of $E$. coli RNA polymerase. J. Biol. Chem. 244: $6160 \sim 6167,1969$

2) Berg, D.; K. Barrett \& M. Chamberlin: Purification of two forms of $E$. coli RNA polymerase and of sigma component. In Methods in Enzymology. Vol. 21. Eds., L. Grossman \& K. Moldave, pp. 506 519, Academic Press, New York, 1971

3) MANGeL, W. F.: Initial steps in the large-scale purification of $E$. coli RNA polymerase. Arch. Biochem. Biophys. 163: 172 177, 1974

4) WeHRLI, W.; F. KNÜSEL, J. NüESCH \& M. STAEHELIN: Interaction of rifamycin with bacterial RNA polymerase. Proc. Natl. Acad. Sci. U.S.A. 61: 667 673, 1968

5) Felix, H. R. \& W. WeHRLI: RNA synthesis in E. coli cells made permeable to nucleoside triphosphates by various methods. Experientia 34: 1667, 1978

6) Vosberg, H. P. \& H. Hoffmann-Berling: DNA synthesis in nucleotide-permeable $E$. coli cells. I. Preparation and properties of ether-treated cells. J. Mol. Biol. 58: 739 753, 1971

7) Glover, S. W.: Luria \& Delbrück fluctuation test. In Experiments in Microbial Genetics. Eds., R. C. Clowes \& W. Hayes, pp. $22 \sim 26$, Blackwell, Scientific Publication, Oxford, 1968

8) Kump, W. \& H. BickeI: Zur Kenntnis von Rifamycin-S. Helv. Chim. Acta 56: 2348 2377, 1973

9) Wehrli, W.: Ansamycins, chemistry, biosynthesis and biological activity. Top. Curr. Chem. 72: 21 49,1977

10) WeHrLI, W.: Rifampicin, mechanism of action and resistance. Rev. Infect. Dis. 5 (Suppl. 3): S407 S411, 1983

11) Schmidt, G.; B. JANN \& K. JANN: Immunochemistry of R lipopolysaccharides of E. coli. Eur. J. Biochem. 16: 382 392, 1970

12) Oppolzer, W.; V. Prelog \& P. Sensi: Konstitution des Rifamycins $\mathbf{B}$ und verwandter Rifamycine. Experientia 20:336 339, 1964 